\begin{tabular}{|c|c|c|c|c|}
\hline JURNAL & NOMOR 2 & HALAMAN 100-110 & $\begin{array}{l}\text { ISSN 2655-8823 }(p) \\
\text { ISSN 2656-1786 }(e)\end{array}$ \\
\hline KOLABORASI RESOLUSI KONFLIK & VOLUME 2 & NOMS \\
\hline
\end{tabular}

\title{
MEMAHAMI CYBERBULLYING DI KALANGAN REMAJA
}

\author{
Binahayati Rusyidi \\ Departemen Kesejahteraan Sosial dan Pusat Riset Gender dan Anak Universitas Padjadjaran \\ E-mail: binahayati@unpad.ac.id
}

\begin{abstract}
ABSTRAK
Cyberbullying di kalangan remaja merupakan isu yang relatif baru yang saat ini dipandang sebagai sebuah isu global. Masalah tersebut dapat terjadi di negara manapun tanpa memandang tingkat perkembangan sosialekonomi suatu wilayah. Cyberbullying menimbulkan dampak negatif terhadap kondisi psikososial and capaian akademik korban. Artikel ini merupakan kajian literature yang bertujuan mendiskusikan beberapa aspek dasar cyberbullying seperti definisi, tipe-tipe, faktor-faktor resko dan pelindung serta model intervensi cyberbullying. Artikel ini menunjukkan pendefinisian cyberbullying masih terus berkembang seiring dengan tingginya dinaika perkembangan teknologi informasi dan komunikasi yang memfasilitasi terjadinya cyberbullying. Cyberbullying terjadi melalui berbagai media dan meliputi beragam bentuk. Faktor-faktor pelindung dan resiko cyberbullying dapat ditemulan di berbagai level mulai dari kondisi dan karakteristik individu, lingkungan pertemanan, dan lingkungan keluarga. Hal ini menggarisbawahi pentingnya penanganan-penanganan yang bersifat multidimensi dalam mengatasi cyberbulling di kalangan remaja. Namun demikian model pencegahan dan intervensi yang cocok untuk cyberbullying belum terbangun dengan baik.
\end{abstract}

Kata kunci: definisi cyberbullying, masalah perilaku, tipe-tipe cyberbullying, faktor resiko dan pelindung.

\section{PENDAHULUAN}

Perundungan (bullying) di kalangan remaja merupakan salah satu isu yang menyita perhatian para pendidik, peneliti, dan masyarakat di berbagai negara. Penelitian mengenai perundungan di kalangan remaja dimulai pada era 1970-an di negara-negara Barat (Newey and Magson, 2010) namun saat ini masalah tersebut sudah dianggap sebagai isu global yang terjadi di berbagai belahan dunia (Unicef, 2019). Dalam 2 dekade terakhir, para ahli dan peneliti mulai memfokuskan perhatian pada bentuk perundungan terkini di kalangan remaja yaitu cyberbullying. Meningkatnya penggunaan teknologi informasi dan perangkat komunikasi modern di kalangan anak ditenggarai menimbulkan kerentanan baru yang dapat menyebabkan anak terlibat dalam cyberbullying baik sebagai pelaku maupun korban (Fanti dkk., 2008).

Berbagai penelitian lintas negara menunjukkan bahwa cyberbullying merupakan masalah yang mengkhawatirkan baik di negara-negara maju maupun wilayah berkembang. Hinduja dan Patchin, 2006) dalam studinya terhadap 1378 remaja di Amerika
Serikat menemukan bahwa prevalensi pengalaman bullying berada pada kisaran 17 persen (sebagai pelaku) dan 34 persen sebagai korban. Sebuah studi multinasional oleh Atanashiou dkk. (2008) di kalangan remaja di 7 negara Eropa: Romania, Jerman, Yunani, Polandia, Belanda, Iceland, dan Spanyol menemukan pengalaman bullying berkisar pada angka 13 hingga 37\%). Proporsi remaja yang melaporkan pernah menjadi cyberbullying dalam 12 bulan terakhir sebanyak $37 \%$ di Romania (tertinggi), 27\% di Jerman, dan $13 \%$ di Belanda (terendah). Sebuah hasil pooling yang dilakukan oleh UNICEF terhadap lebih dari 170 ribu remaja dan dewasa muda berusia 13 s sampai dengan 24 tahun di 27 negara di Asia, Afrika, Eropa, Amrika Latin, dan Mediterania (sebagian besar wilayah negara berkembang) termasuk Indonesia menunjukkan bahwa 1 dari 3 responden pernah mengalami bullying online. Fakta ini mematahkan anggapan bahwa bullying hanya merupakan isu sentral bagi negaranegara maju. (UNICEF, 2019).

Sebagai suatu bentuk kekerasan, cyberbullying menimbulkan berbagai dampak negatif terhadap korban. 


\begin{tabular}{|c|c|c|c|c|}
\hline JURNAL & VOLUME 2 & NOMOR 2 & HALAMAN 100-110 & $\begin{array}{l}\text { ISSN 2655-8823 }(p) \\
\text { ISSN 2656-1786 }(e)\end{array}$ \\
\hline
\end{tabular}

Tokunaga (2010) menggarisbawahi bahwa dampak bullying terhadap korban tergantung pada frekuensi, jangka waktu dan keparahan tindakan perundungan yang dialami korban. Semakin serius bentuknya, semakin lama terjadinya dan semakin sering frekuensinya maka akan semakin besar kemungkinan korban mengalami dampak negatif.

Dampak cyberbullying yang dikaji dalam literatur setidaknya dikategorikan ke dalam 2 kelompok utama yaitu dampak terhadap kondisi psikososial korban dan dampak terhadap performa akademik. Para peneliti menunjukkan cyberbullying menimbulkan dampak negatif terhadap kondisi afeksi korban seperti depresi (Didden dkk, 2009), melemahnya rasa penghargaan terhadap diri sendiri (Didden dkk, 2009; Katzer dkk, 2009), tekanan emosi, kemarahan dan kesedihan (Patchin \& Hinduja, 2006). Penelitian Sourander dkk. (2010) terhadap 2215 remaja berusia 13-16 tahun di Finlandia menunjukkan korban cyberbullying lebih rentan mengalami gangguan emosi dan gangguan hubungan pertemanan serta problem psikosomatis seperti sakit kepala, sakit perut berulang, atau gangguan tidur dibandingkan yang bukan korban. Barlett \& Coyne (2014) menggarisbawahi bahwa korban cyberbullying juga cenderung memiliki keinginan bunuh diri.

Berbagai penelitian secara konsisten menunjukkan pengaruh negatif cyberbullying terhadap capaian akademik korban. Beran dan Li (2006) menemukan bahwa anak yang dibully secara online dan secara langsung di sekolah menghadapi berbagai kesulitan dalam proses pembelajaran seperti mendapatkan nilai yang rendah, mengalami gangguan konsentrasi dan absen dari sekolah. Penelitian Katzer dkk. (2009) juga menunjukkan bahwa cyberbullying menyebabkan korban sering tidak masuk sekolah, bolos dan memandang sekolah sebagai tepat yang tidak aman. Para ahli memandang bahwa gangguan terhadap capaian akademik korban dinilai disebabkan oleh gangguan konsentrasi belajar dan tingginya tingkat frustrasi yang dialami oleh korban cyberbullying (Beran \& Li, 2007; Patchin \& Hinduja, 2006).

Namun demikian tidak dapat dipungkiri bahwa kajian-kajian mengenai cyberbullying di kalangan remaja saat ini umumnya dilakukan di negara-negara maju, khususnya di wilayah Amerika Utara dan Eropa (Misal, 2006; Ybarra \& Mitchell, 2004; Slonje \& Smith, 2007; Sourander dkk, 2015; Vandeboch \& Cleemput, 2009). Penelitian-penelitian serupa di negara-negara non Barat masih sangat terbatas sehingga memunculkan gap pengetahuan yang mendasar. Sejalan dengan mengglobalnya isu tersebut cyberbullying dikategorikan sebagai salah satu bentuk kekerasan yang melibatkan anak karena pelaku dan korban sama-sama berstatus sebagai anak. Oleh karenanya UNICEF menjadikan cyberbullying sebagai salah satu isu prioritas yang harus ditangani demi memenuhi hak-hak anak terutama dalam melindungi anak-anak dari tindak kekerasan. Hal ini ditegaskan oleh Direktur Eksekutif UNICEF Henrietta Fore sebagai berikut:

"Thirty years after the adoption of the Convention on the Rights of the Child and the creation of the World Wide Web, it is time for governments, families, academia and the private sector to put children and young people at the centre of digital policies. By protecting them from the worst the Internet has to offer and expanding access to its best, we can each help tip the balance for good." (UNICEF, 2019: h.1)

Artikel ini bertujuan untuk membahas aspek-aspek dasar terkait dengan pemahaman mengenai cyberbullying di kalangan remaja. Pembahasan difokuskan pada konseptualisasi/ pendefinisian cyberbullying, bentuk-bentuk cyberbullying, dampak cyberbullying, faktor-faktor resiko dan pelindung terkait dengan keterlibatan remaja dengan cyberbullying dan model pencegahan dan 


\begin{tabular}{|c|c|c|c|c|}
\hline JURNAL & \multirow{2}{*}{ VOLUME 2 } & NOMOR 2 & HALAMAN 100-110 & $\begin{array}{l}\text { ISSN 2655-8823 }(p) \\
\text { ISSN 2656-1786 }(e)\end{array}$ \\
\hline
\end{tabular}

penanganan. Artikel ini merupakan suatu kajian literature yang sepenuhnya didasarkan pada analisa literature relevan yang sudah ada dan dipublikasikan di sumber-sumber ilmiah, khususnya yang bereputasi internasional. Pencarian artikel dilakukan dengan menggunakan kata kunci yang relevan pada berbagai sistem database yang terpercaya seperti PsycInfo dan Google Scholar maupun website resmi berbagai lembaga terkait di tingkat nasional dan internasional.

\section{PEMBAHASAN}

\section{Konseptualisasi Cyberbullying}

Sebelum membahas definisi cyberbullying, kita terlebih dahulu perlu memahami definisi bullying. Istilah bullying mulai dikenal melalui penelitian di era 1970-s (Newey \& Magson, 2010). Whitney, Smith \& Olweus (1999) mengkonseptualisasi perundungan (bullying) sebagai tindakan atau perilaku agresif yang dilakukan dengan sengaja oleh seseorang atau sekelompok orang secara berulang-ulang dan dalam rentang waktu tertentu terhadap seorang korban yang tidak mampu untuk melawan. Para ahli dan peneliti membedakan bullying ke dalam 2 kelompok besar yaitu bullying atau traditional bullying dan cyberbullying di mana keduanya memiliki beberapa kesamaan maupun karakter yang unik sebagai pembeda (Tokunaga, 2010).

Traditional bullying, menurut Orpinas \& Horne (2005) merupakan penyalahgunaan kekuasaan oleh pelaku terhadap target atau korban dalam berbagai bentuk. Pelaku perundungan menurut Olweus (1993) biasanya lebih kuat/memiliki kuasa lebih secara fisik, sosial atau psikologis dibandingkan korban. Olweus melanjutkan bahwa ketidakseimbangan kuasa yang disalahgunakan oleh pelaku untuk mengontrol, melukai dan melakukan serangan berulang-ulang dalam jangka waktu tertentu itulah yang menjadi karakteristik dasar bullying. Sejalan dengan pernyataan di atas Cross dkk.
(2015) menggarisbawahi suatu tindakan disebut sebagai berbullying jika terpenuhinya 3 (tiga) unsur yaitu: tindakan yang berulang, relasi kuasa yang tidak seimbang antara pelaku dan korban, dan adanya maksud yang jelas untuk menyakiti korban.

Traditional bullying mencakup perundungan fisik berupa tindakan yang dilakukan secara sengaja oleh pelaku terhadap seseorang yang berpotensi menimbulkan luka atau bahaya fisik seperti memukul, menendang, berkelahi menggunakan senjata meninju, merampas atau merusak barang milik korban. Bentuk lain dari traditional bullying adalah agresi verbal berupa penggunaan kata-kata yang secara sengaja ditujukan untuk menyakiti mental seseorang seperti mengolok-olok, merendahkan, meneriaki dan memaksa (Olweus, 1993; Orpinas \& Horne, 2006). Bentuk traditional bullying kemudian juga diperluas mencakup apa yang disebut sebagai social/relational aggression yang meliputi tindakan agresi yang bersifat tidak langsung (dilakukan melalui pihak ketiga) dan bertujuan merusak hubungan pertemanan seseorang) atau harga diri atau status sosial seseorang (Underwood, 2002). Sebagian besar peneliti (Monks \& Smith, 2006) saat ini menganggap bahwa tindakan agresif yang bersifat tidak langsung seperti menyebarluaskan cerita yang buruk dan agresi relasional/sosial atau tindak pengucilan sosial seperti meminta orang lain untuk tidak bermain/berteman dengan seseorang termasuk bentuk-bentuk tindakan bullying. Traditional bullying di kalangan remaja umumnya terjadi di lingkungan sekolah dan luar sekolah yang mendapat perhatian yang sangat luas dari para peneliti di berbagai negara (Fanti dkk, 2012; Tokunaga, 2010).

Sementara itu cyberbullying dapat dikatakan merupakan fenomena empirik dan tema penelitian yang relatif baru dibandingkan traditional bullying. Cyberbullying mulai menjadi perhatian para ahli sejak satu dekade terakhir seiring 


\begin{tabular}{|c|c|c|c|c|}
\hline JURNAL & \multirow{2}{*}{ VOLUME 2 } & NOMOR 2 & HALAMAN 100-110 & $\begin{array}{l}\text { ISSN 2655-8823 }(p) \\
\text { ISSN 2656-1786 }(e)\end{array}$ \\
\hline
\end{tabular}

dengan meningkatnya penggunaan perangkat teknologi komunikasi modern dan virtual di kalangan anak-anak. Cyberbullying dimediasi melalui penggunaan telepon seluler, iPads, online chat, email, websites, jaringan media sosial personal (misal: Facebook, Twitter, MySpace), telpon, video clips, instant messenger (IMs), dan sebagainya untuk melakukan tindakan perundungan terhadap seseorang (Aricak dkk., 2008; Smith dkk., 2008).

Para ahli belum menemukan kesepakatan mendasar mengenai definisi cyberbullying karena masih terus berkembangnya isu-isu konseptual terkait cyberbullying. Di samping itu karena perkembangan teknologi informasi yang sangat dinamis, para ahli masih mendefinisikan cyberbullying secara beragam mengingat adanya berbagai perbedaan dalam menunjukkan teknologi siber yang digunakan dan metode-metode yang dipakai oleh pelaku untuk menyakiti dan melukai korbannya (Kowalski, Limber \& Agatson, 2008). Beranjak dari keberagaman dan ketidakajegan dalam pendefinisian cyberbullying dalam berbagai litertur, eta analisa yang dilakukan Tokugawa (2010) mencoba memformulasikan satu definisi yang dianggap dapat menyatukan berbagai perbedaan tersebut. Menurut Tokunaga (h.10), cyberbullying adalah "any behavior performed through electronic or digital media by individuals or groups that repeatedly communicates hostile or aggressive messages intended to inflict harm or discomfort on others". Cyberbullying bersifat langsung ketika pelaku secara privat membully korban dengan mengirim pesan melalui SMS atau email (Langos, 2012) dan tidak langsung manakala pelaku melibatkan pertolongan pihak lain untuk membully korban (Sleglova \& Cerna, 2011; Snakenborg, Van Acker, \& Gable, 2011).

Di samping berbagai persamaan, cyberbullying memiliki karakteristik yang membedakannya dari traditional bullying.
Beberapa ahli memandang perbedaan karakteristik tersebut dapat memfasilitasi timbulnya pengaruh negatif yang lebih besar terhadap korban dibandingkan traditional bullying. Ciri pertama, korban cyberbullying mengalami kesulitan untuk menjauh dari tindakan perundungan karena penggunaan media online/virtual menyebabkan pelaku dapat terhubung dengan korban kapan saja. Karenanya korban akan terus menerima teks, pesan atau email kapanpun dan di manapun mereka berada. Hal ini berbeda dengan traditional bullying yang umumnya terjadi pada lokasi tertentu (misal di sekolah) di mana korban dapat menghindarinya ketika tidak berada di sekolah. Perbedaan kedua terletak dari luasnya pihak-pihak yang potensial terlibat atau mengetahui tindakan perundungan yang terjadi. Kedua, cyberbullying dapat menjangkau audiens yang jauh lebih luas dibandingkan dengan perundungan biasa yang umumnya diketahui oleh kelompok terbatas. Misalnya, ketika seseorang mengunggah sebuah gambar atau video clip untuk mempermalukan korban, tayangan tersebut akan dapat disaksikan oleh audiens yang sangat luas sehingga dapat memberikan tekanan emosional dan sosial tambahan kepada korban. Perbedaan ketiga terkait dengan sifat pelaku perundungan yang tidak terlihat nyata (invisible) mengingat cyberbullying bukan merupakan pengalaman yang bersifat tatap muka antara pelaku dan korban. Dengan kata lain, cyberbullying memberikan semacam kesempatan bagi pelaku untuk menjadi tidak dikenal identitasnya (anonym). Berdasarkan karakteristik tersebut, pelaku perundungan sangat mungkin kurang atau tidak menyadari konsekuensi yang ditimbulkan dari tindakannya terhadap korban sehingga sangat kecil peluangnya untuk berempati terhadap korban atau menyesali perbuatannya. Di lain sisi, karena terjadi di domain virtual, cyberbullying mempersempit keterlibatan pihak lain untuk melakukan intervensi 


\begin{tabular}{|c|c|c|c|c|}
\hline JURNAL & VOLUME 2 & NOMOR 2 & HALAMAN 100-110 & $\begin{array}{l}\text { ISSN 2655-8823 }(p) \\
\text { ISSN 2656-1786 }(e)\end{array}$ \\
\hline
\end{tabular}

(Patchin \&Hinduja, 2006; Strom \& Strom, 2005).

Karena itu, Hinduja \& Patchin (2008) mengadvokasi pentingnya perhatian dan penanganan terhadap cyberbullying, terutama di kalangan remaja. Sifat anonymity cyberbullying menimbulkan kesulitan tersendiri bagi korban namun di sis lain memberikan keleluasaan bagi pelaku untuk menjalankan aksinya. Menurut Hinduja \& Patchin (2008):

The nuances of electronic communication are important to discuss in order to demonstrate why the phenomenon of cyberbullying deserves attention. To begin, the elements of perceived anonymity online, and the safety and security of being behind a computer screen, aid in freeing individuals from traditionally constraining pressures of society, conscience, morality, and ethics to behave in a normative manner. The use of pseudonyms or pseudonymous email or user accounts also makes it difficult for victims to easily determine the identity of offenders, and also presumably contributes to the freedom an offender has on the internet (h.134).

\section{Tipe Cyberbullying}

Para ahli membedakan tipe cyberbullying berdasarkan metode yang digunakan. Dalam kajian literaturnya, Newey \& Magson (2010) meringkas paling tidak terdapat 9 (sembilan) macam tipe cyberbullying. Ke-9 tipe tersebut dijelaskan sebagai berikut di bawah ini.

1. Flaming

Flaming merupakan suatu tipe perundungan, misalnya ruang diskusi atau chatting, di mana individu-individu atau kelompokkelompok menjadi target pesanpesan yang bernada marah dan tidak sopan melalui media publik online. Jika perselisihan verbal tersebut meningkat dengan menggunakan bahasa vulgar dan menyakiti orang lain maka hal tersebut dianalogikan seperti mulainya api (flaming) peperanga

2. Pelecehan online (Online harassment)

Pelecehan online didefinisikan sebagai pengiriman teks pesan atau email yang bersifat menyerang secara berulang-ulang atau terus menerus yang ditujukan pada suatu target tertentu dengan tujuan mengganggu atau melukai perasaan seseorang.

3. Pencurian identitas (Identity theft/impersonation)

Pencurian identitas muncul ketika pelaku perundungan berpura-pura menjadi orang lain dan membobol atau mendapatkan kata sandi akun korban dan memudian menyalahgunakan akun online tersebut dengan mengirimkan informasi yang menyakiti dan membahayakan korban kepada teman-teman korban. Sebagai contoh, murid sekolah membobol akun korban dan memposting informasi yang tidak benar atau memalukan mengenai korban pada media online tertentu untuk dibaca orang lain dan secara digital mengedit foto-foto dengan sengaja untuk membuat korban terlihat jelek atau buruk.

4. Outing

Outing merupakan tindakan mengirim atau memposting informasi yang bersifat pribadi dan rahasia secara online mengenai korban kepada pihak lain. Dalam outing, terjadi pembocoran rahasia secara sengaja kepada pihak luas karena semula korban mempercayakan kepada pelaku untuk menyimpan/menjaga informasi tersebut sebagai rahasia.

5. Pengucilan (Exclusion/ostracism)

Pengucilan umumnya muncul ketika target perundungan diblokir atau dihapus dari daftar pertemanan, disingkirkan dari grup 


\begin{tabular}{|c|c|c|c|c|}
\hline JURNAL & VOLUME 2 & NOMOR 2 & HALAMAN 100-110 & $\begin{array}{l}\text { ISSN 2655-8823 }(p) \\
\text { ISSN 2656-1786 }(e)\end{array}$ \\
\hline
\end{tabular}

online oleh pelaku atau ketika teman-teman secara sengaja tidak merespon pesan atau email yang dikirimkan oleh korban dengan tujuan menyakiti korban.

6. Misinformation/Denigration

Misinformation/denigration

merujuk pada penyebarluasan informasi yang tidak benar dan membahayakan seseorang melalui laman website, email, teks pesan atau short messages services. Termasuk di dalamnya ketika murid-murid memposting informasi yang tidak benar, memalukan dan menyakitkan mengenai korban atau secara digital mengubah foto sehingga membuat korban terlihat tidak menarik dan mengundang komentar negatif dari pihak luar.

7. Cyber stalking

Cyber stalking merupakan bentuk pelecehan tingkat lanjut dan biasanya tindakan ini meliputi tindakan yang mengancam, memata-matai dan mengintimidasi ikorban yang dilakukan pelaku secara berulang-ulang sehingga menimbulkan ketakutan. Sebagai contoh, seorang murid menerima email dari seseorang yang tidak dikenal yang mengandung ancaman untuk melukai secara fisik, memata-matai, atau menguntit korban.

8. Happy slapping

Happy slapping merupakan istilah cyberbullying yang relatif baru yang muncul ketika para pelaku secara sengaja membuli, memukul, menyerang atau membuat korban bahan tertawaan yang direkam dengan video dengan tujuan utama untuk membocorkan video tersebut pada laman publik dan atau mengirim video tersebut melalui email, internet atau telpon seluler kepada orang lain untuk ditonton.
9. Sexting

Sexting didefinisikan sebagai tindakan mengirimkan image seksual seperti foto-foto korban atau pelaku dalam pose telanjang atau setengah telanjang melalui telepon seluler untuk dilihat orang lain.

Berbagai studi menunjukkan beberapa tipe cyberbullying yang umumnya dilakukan remaja. Misalnya, tiga tipe paling umum yang dilakukan pelaku cyberbullying adalah pelecehan online, misinformation, dan outing (Popovic-Citic dkk., 2011). Sementara itu media online yang umumnya digunakan oleh pelaku untuk melakukan cyberbullying berupa pengiriman gambar atau video clip dan telepon untuk menyakiti korban (Slonje \& Smith, 2008).

\section{Faktor Resiko dan Pelindung}

Dibandingkan dengan traditional bullying, penelitian mengenai faktor-faktor resiko dan pelindung cyberbullying jauh lebih terbatas. Bukti empirik menunjukkan bahwa faktor sosio-demografis, faktor individual dan faktor lingkungan berperan dalam melindungi remaja dari cyberbullying atau sebaliknya meningkatkan resiko remaja terlibat dalam cyberbullying. Namun demikian penelitian mengenai faktor resiko dan pelindung masih menghadapi tantangan mengingat sebagian besar merupakan penelitian cross-sectional dan masih minim yang menerapkan pendekatan longitudinal. Selain itu mayoritas kajian masih memusatkan pada satu dimensi lingkungan dan masih sedikit yang menganalisa faktor resiko dan pelindung dalam beragam setting yang mencakup faktor individu, lingkungan pertemanan, lingkungan sekolah dan keluarga (Fanti dkk, 2012).

Jenis kelamin dan usia merupakan variabel sosio-demografis yang paling banyak diteliti. Beberapa penelitian jenis kelamin berasosiasi dengan cyberbullying namun berbagai penelitian lainnya menunjukkan tidak ada perbedaan yang 


\begin{tabular}{|c|c|c|c|c|}
\hline JURNAL & VOLUME 2 & NOMOR 2 & HALAMAN 100-110 & $\begin{array}{l}\text { ISSN 2655-8823 }(p) \\
\text { ISSN 2656-1786 }(e)\end{array}$ \\
\hline
\end{tabular}

signifikan antara remaja laki-laki dan perempuan sebagai pelaku atau korban cyberbullying (Slonje \& Smith, 2008; Mesch, 2009; Fanti dkk, 2012). Usia juga belum dipandang sebagai faktor yang konsisten mempengaruhi cyberbullying. Beberapa penelitian menunjukkan hubungan berlawanan antara usia dan pengalaman cyberbullying bahwa semakin bertambah usia remaja maka semakin turun peluang menjadi korban (Williams \& Guerra, 2007; Slonje \& Smith, 2008). Kedua penelitian tersebut menjelaskan tingginya kerentanan terlibat dalam cyberbullying dalam usia yang lebih muda kemungkinan terkait dengan tingginya dorongan impulsif di kalangan remaja berusia muda.

Faktor-faktor individual yang meningkatkan resiko remaja terlibat cyberbullying terkait dengan pengalaman perundungan, karakteristik kepribadian, dan pola aktivitas remaja. Penelitian menunjukkan bahwa pelaku cyberbullying sebelumnya juga merupakan korban cyberbullying atau traditional bullying (Barlett \& Coyne, 2014; Gradinger dkk, 2009). Sebaliknya, mereka yang pernah menjadi korban traditional bullying juga rentan mengalami cyberbullying (Gradinger dkk., 2009; Hinduja \& Patchin,2006; Katzer dkk., 2009; Beran \& $\mathrm{Li}$, 2006). Penelitian juga menunjukkan bahwa pelaku cyberbullying cenderung berperilaku melanggar norma sosial, menggunakan zat terlarang, dan agresif (Hinduja \& Patchin,2006; Sourander dkk, 2010). Mesch (2009) menemukan bahwa remaja yang bersedia untuk berbagi informasi personal kepada pihak lain secara online berisiko lebih tinggi menjadi sasaran cyberbullying dibandingkan dengan mereka yang membatasi pengungkapan informasi personal kepada pihal lain. Vandebosch \& Cleemput (2009) menemukan bahwa korban cyberbullying umumnya merupakan individu yang tergantung pada penggunaan internet, merasa tidak popular, dan melakukan aktivitas online yang berisiko. Sementara itu Fanti dkk. (2012) menemukan bahwa pelaku cyberbullying umumnya merupakan individu yang kurang peduli dan tidak berempati terhadap kesulitan orang lain dan sering terpapar kekerasan online. Keterpaparan remaja pada kekerasan online secara terus menerus menumbuhkan pemahaman dan sikap yang menganggap agresivitas sebagai hal yang normal atau bahan ditoleransi di satu sisi dan menumpulkan empati mereka terhadap korban.

Lingkungan pertemanan juga mempengaruhi resiko remaja terlibat dalam cyberbullying. Dalam studinya di kalangan remaja Israel, Sasson dan Mesch (2014) menemukan bahwa persepsi remaja mengenai dukungan teman untuk melakukan cyberbullying meningkatkan resiko remaja untuk melakukan tindakan berisiko online. Para peneliti menjelaskan bahwa persepsi mengenai dukungan teman sebaya melemahkan pengaruh pengawasan ketat yang dilakukan oleh orang tua. Dengan kata lain, jaringan pertemanan yang mendukung cyberbullying menjadi faktor resiko yang mendorong keterlibatan remaja melakukan tindaj perundungan.

Di lingkungan keluarga, status sosial orangtua dan hubungan orangtua dan anak merupakan salah satu faktor pelindung. Penelitian Tsitsika dkk. (2015) menunjukkan bahwa keterlibatan dalam cyberbullying baik sebagai pelaku maupun korban lebih tinggi di kalangan remaja yang memiliki orangtua berpendidikan rendah atau menangah dibandingkan dengan renaja dengan orangtua berpendidikan tinggi. Penelitian Fanti dkk. (2012) terhadap lebih dari 1400 remaja di Cyprus menunjukkan dukungan keluarga mengurangi resiko remaja menjadi korban cyberbullying ketika lingkungan pertemanan dipandang tidak mendukung.

Sementara itu Cerna dkk. (2016) dalam penelitian terhadap 1395 remaja di wilayah Uni Eropa menunjukkan keterlibatan orangtua yang bersifat aktif (active mediation) menjadi faktor pelindung yang mengurangi resiko remaja terlibat dalam 


\begin{tabular}{|c|c|c|c|c|}
\hline JURNAL & \multirow{2}{*}{ VOLUME 2 } & NOMOR 2 & HALAMAN 100-110 & $\begin{array}{l}\text { ISSN 2655-8823 }(p) \\
\text { ISSN 2656-1786 }(e)\end{array}$ \\
\hline
\end{tabular}

cyberbullying. Active mediation pada prinsipnya menekankan hubungan kerjasama anak dan orangtua yang dilandasi oleh kepercayaan dan kelekatan yang sehat seperti komunikasi yang terbuka dan konsistensi atas aturan penggunaan internet (durasi, pihak yang boleh diajak berkomunikasi, laman yag boleh dikunjungi atau tidak). Penelitian ini juga menunjukkan, semakin banyak orangtua mengetahui aktivitas online anak maka semakin besar kemungkinan anak mengungkapkan pengalaman cyberbullying yang dialaminya. Kondisi ini dipandang sebagai faktor pelindung karena dapat meningkatkan dukungan orangtua untuk menghindarkan anak dari cyberbullying yang berkelanjutan. Sebaliknya, menurut Cerna dkk. (2012) komunikasi yang tidak baik antara anak dan orangtua menghalangi anak untuk berterusterang atas pengalaman cyberbullying sehingga menghambat keterlibatan orangtua untuk memberikan bantuan. Davis \& Koepke (2014) Juga menemukan remaja yang melaporkan hubungan yang sangat baik dengan orangtua lebih rendah resikonya mengalami cyberbullying.

\section{Model Intervensi}

Cantone dkk. (2015) melakukan review atas berbagai model intervensi dalam pencegahan dan penanganan bullying dan cyberbullying. Hasil kajian menunjukkan adanya 3 (tiga) model utama intervensi yaitu "Focused intervention", "Universal intervention" dan "Whole School intervention". Namun demikian hampir seluruh model tersebut diimplementaskan di wilayah negaranegara maju sehingga kurang merefleksikan konteks masalah dan kebutuhan negara-negara berkembang.

Focused intervention model dicirikan dengan model intervensi berbasis individu dan kelompok kecil yang dilandasi oleh asumsi-asumsi teori cognitive-behaviour. Target intervensi adalah murid-murid yang terdeteksi mengalami kecemasan sosial dan menjadi korban bullying. Intervensi umumnya diarahkan membangun kompetensi keterampilan sosial. Focused intervention juga dapat melibatkan orangtua anak melalui kegiatan-kegiatan yang dilaksanakan di sekolah. Universal intervention dilandasi asumsi teoritis bahwa iklim sekolah berperan dalam tindakan bullying sehingga intervensi diarahkan untuk mengubah iklim sekolah dengan tujuan untuk mencegah bullying. Intervensi berbasis sekolah dengan bersandarkan pada manual-manual yang disusun untuk menuntun implementasi. Intervensi universal juga terditi atas program-program pertemuan dan pelatihan bagi orangtua di sekolah atau aktivitas terstruktur lainnya di rumah. Sementara itu whole school intervention merupakan aktivitas bebasis sekolah. Intervensi ini didasarkan pada asumsi pentingnya meningkatkan kondisi lingkungan sosial untuk mencegah dan menangani bullying. Model ini mencakup kegiatan-kegiatan yang memperkenalkan dan menerapkan aturan-aturan yang menolak perilaku bullying, memberikan sanksi atas perilaku perundungan dan meningkatkan kesadaran komunitas sekolah bahwa bullying tidak dapat ditoleransi (Cantone dkk, 2015).

Meta analisa yang dilakukan oleh Gayneyy dkk. (2019) menunjukkan efektivitas berbagai intervensi untuk mencegah cybullying di kalangan remaja sehingga dapat direplikasi. Namun demikian model-model tersebut umumnya diterapkan di wilayah negara Barat dan maju sehingga belum mewakili kepentingan negara-negara berkembang dan memerlukan semacam modifikasi dalam model atau desain intervensi. Artikel ini menggarisbawahi mengingat keberagaman faktor resiko dan pelindung tersebut para peneliti dan praktisi memandang perlu upaya serius untuk mencegah dan menangani cyberbullying dengan melibatkan berbagai kelembagaan di level mikro dan makro. Ini berarti intervensi untuk mencegah dan menangani cyberbullying di kalangan remaja bukan 


\begin{tabular}{|c|c|c|c|c|}
\hline JURNAL & VOLUME 2 & NOMOR 2 & HALAMAN 100-110 & $\begin{array}{l}\text { ISSN 2655-8823 }(p) \\
\text { ISSN 2656-1786 }(e)\end{array}$ \\
\hline
\end{tabular}

hanya harus melibatkan anak tetapi juga orangtua, komunitas pendidikan, pemerintah dan masyarakat luas. PopoficCitic dkk. (2011) menegaskan:

Cyberbullying has increased very quickly and educators and researchers are understandably concerned that this problem is growing more rapidly than educators' and parents' ability to respond effectively. [...] itis necessary to create a comprehensive and proactive system in order to react to cyberbullying, which would combine technical/software, legal, psychological, educational and social intervention measures, and would demand the active engagement of children, parents, teachers and other subjects in the local community, with the aim of facing the problem of cyberbullying and encouraging healthy styles of communication in the virtual world. [...] a policy established by the government, are needed in order to ensure that cyberbullying is recognized as a social phenomenon [...]. Adequate sensitivity on behalf of governors, administrators, teachers and parents is a prerequisite for successful prevention and intervention programs. Educating students about cyberbullying and instructing them about how to handle incidents if they occur appears to be of increasing importance. Students need to know of strategies that will increase the chance of identifying the perpetrator, and they should also be encouraged to tell adults when they witness or are targeted by cyberbullying (p.421).

\section{KESIMPULAN}

Cyberbullying berkembang cepat menjadi salah satu isu krusial di kalangan remaja. Cyberbullying menimbulkan berbagai dampak negatif yang dapat menghambat tumbuh kembang remaja yang tidak hanya menyebabkan kesulitan sesaat namun juga dalam jangka panjang. Dengan pesatnya perkembangan teknologi informasi dan komunikasi serta karakteristik uniknya maka diperlukan keterlibatan berbagai pihak terkait untuk memahami dan menyadari permasalahan tersebut sebagai masalah yang serius. Menurut Sourander dkk. (2010), karakteristik unik cyberbullying yang berpotensi menjangkau target atau bystander yang luas serta sifatnya yang anonym menjadikan pemecahannya menjadi lebih kompleks dibandingkan traditional bullying. Pemahaman faktor resiko menuntut dilakukannya pencegahan dan penanganan yang bersifat multi dimensi mengingat tidak ada satu faktor tunggal yang meningkatkan resiko remaja terlibat dalam cyberbullying. Penelitian mengenai faktor pelindung perlu diperluas sehingga dapat dikembangkan untuk meningkatkan resiliensi remaja terhadap cyberbullying.

Kajian ini menunjukkan masih sangat terbatasnya penelitian mengenai prevalensi, pengalaman cyberbullying, faktor resiko dan pelindung serta implementasi model intervensi penanganan cyberbullying di negaranegara berkembang. Hal ini menggarisbawahi pentingnya perhatian dari para peneliti di wilayah negara-negara berkembang sehingga dapat berkontribusi mengurangi gap pengetahuan serta membantu penanganan permasalahan yang berbasis evidence dan memperhatikan konteks khusus kewilayahan.

\section{DAFTAR PUSTAKA}

Aricak, T., Siyahhan, S., Uzunhasanoglu, A., Saribeyoglu, S., Ciplak, S., Yilmaz, N., \& Memmedov, C. (2008). Cyberbullying among Turkish adolescents. CyberPsychology \& Behavior, 11(3), 253-261. doi:10.1089/cpb.2007.0016

Athanasiou, K., Melegkovits, E., Andrie, E.K. Magoulas, C., Tzavara, C.K., Richardson, C., Greydanus, D., Tsolia, M., \& Tsitsika, A.K. (2018). Crossnational aspects of cyberbullying victimization among 14-17-year-old 


\begin{tabular}{|c|c|c|c|c|}
\hline JURNAL & \multirow{2}{*}{ VOLUME 2 } & NOMOR 2 & HALAMAN 100-110 & $\begin{array}{l}\text { ISSN 2655-8823 }(p) \\
\text { ISSN 2656-1786 }(e)\end{array}$ \\
\hline
\end{tabular}

adolescents across seven European countries. BMC Public Health, 18.

Barlett, C. \& Coyne, S.M. (2014). A metaanalysis of sex differences in cyberbullying behaviour: The moderating role of age. Journal of Aggressive Behavior. DOI:10.1002/ab.2155.

Beran, T., \& Li, Q. (2005). Cyberharassment: A study of a new method for an old behavior. Journal of Educational Computing Research, 32, 265-277.

Cantone, E., Piras, A.P., Vellante, M. et al. (2015). Interventions on bullying and cyberbullying in schools: a systematic review. Clinical Practice Epidemiology Mental Health, 11(Suppl 1 M4):58-76.

Didden, R., Scholte, R.H.J., Korzilius, H., de Moor, J.M.H., Vermeulen, A., O'Reilly, M., Lang, R. and Lancioni, G.E. (2009) Cyberbullying among Students with Intellectual and Developmental Disability in Special Education Settings. Developmental Neurorehabilitation, 12, 146-151.

Fanti, K.A., Demetriou, A.G. \& Hawa, V.V. (2012). A longitudinal study of cyberbullying: Examining risk and protective factors. European Journal of Developmental Psychology, 9 (2), 168181.

Gaffney, H, Farringtona, D.P., Espelageb, D.L., \& Ttofi, M.M. (2019). Are cyberbullying intervention and prevention programs effective? A systematic and meta-analytical review. Aggression \& Violent Behavior, 45, 134-1532019.

Gradinger, P., Strohmeier, D., \& Spiel, C. (2009). Traditional bullying and cyberbullying: Identification of risk groups for adjustment problems. Zeitschrift fu "r Psychologie/Journal of Psychology, 217, 205-213.

Katzer, C., Fetchenhauer, D., \& Belschak, F. (2009). Cyberbullying: WhoAretheVictims? A Comparison of Victimization in Internet Chatrooms and Victimizationin School. Journal of Media Psychology, 21(1):25-36.

Kowalski, R.M., Limber, S.P., \& Agatston, P.W. (2008). Cyber Bullying. Bullying in the Digital Age. Oxford: Blackwell.

Langos, C. (2012). Cyberbullying: The challenge to define. Cyberpsychology, Behavior, and Social Networking, 15(6), 285-289.

Mesch, G.S. (2009). Parental Mediation, Online Activities, and Cyberbullying. CyberPsychology \& Behavior, 12 (4).

Olweus, D. (1993). Bullying at school: What do we know and what can we do. Cambridge, MA: Blackwell.

Orpinas, P. \& Horne, A. M. (2006). Bullying Prevention: Creating a Positive school Climate and Developing Social Competence. Washington, DC: American Psychological Association.

Patchin, J. \& Hinduja, S. (2006). Bullies Move Beyond the Schoolyard: A Preliminary Look at Cyberbullying. Violence \& Abuse Abstracts, 12 (3): 148-169.

Popovic-Citic, B., Djuric, S., \& Cvetkovic, V. (2011). The prevalence of cyberbullying among adolescents: A case study of middle schools in Serbia. School Psychology International, 32: 412-424.

Sasson, H. \& Mesch, G.S. (2014). Parental Mediation, Peer Norms and Risky Online Behaviors among Adolescents. Computers in Human Behavior, 33, 32-38.

Slonje, R., \& Smith, P. K. (2008). Cyberbullying: Another main type of bullying? Scandinavian Journal of Psychology, 49, 147-154.

Smith, P. K., Mahdavi, J., Carvalho, M., Fisher, S., Russell S., \& Tippett, N. (2008). Cyberbullying: Its nature and impact in secondary school pupils. The Journal of Child Psychology and Psychiatry, 49(4), 376-385. doi:10.1111/j.14697610.2007.01846.x 


\begin{tabular}{|c|c|c|c|c|}
\hline JURNAL & VOLUME 2 & NOMOR 2 & HALAMAN 100-110 & $\begin{array}{l}\text { ISSN 2655-8823 }(p) \\
\text { ISSN 2656-1786 }(e)\end{array}$ \\
\hline
\end{tabular}

Strom, P. S., \& Strom, R. D. (2005). When teens turn cyberbullies. The Educational Digest, 71, 35-41.

Sourander, A., Klomek, A.B., Ikonen, M., Lindroos, J., Luntamo, T., Koskelainen, M., Ristkari, T, \& Helenius, H. (2010). Psychosocial Risk Factors Associated With Cyberbullying among Adolescents: A Population-Based Study. Arch Gen Psychiatry, 67 (7).

Tokunaga, R. S. (2010). FollowingYou HomefromSchool: A Critical Reviewand Synthesis of Research on Cyberbullying Victimization. Computers in Human Behavior 26 (3): 277-287.

Underwood, M. K. (2002). Sticks and stones and social exclusion: Aggression among girls and boys. In P. K. Smith \& C. H. Hart (Eds.), Blackwell Handbook of Childhood Social Development (pp. 533-548). Oxford: Blackwell
UNICEF. (5 Februari 2019). Safer Internet Day: UNICEF calls for concerted action to prevent bullying and harassment for the over 70 per cent of young people online worldwide. Diunduh pada 1 Juli 2020 melalui https://www.unicef.org/eca/pressreleases/safer-internet-day-unicefcalls-concerted-action-preventbullying-and-harassment

Vandebosch, H. \& van Cleemput, K. (2009). Cyberbullying Among Youngsters: Profiles of Bullies and Victims. New Media \& Society, 11 (8): 1349-1371.

Williams, K.R. \& Guerra, N.G. (2007). Prevalence and Predictors of Internet Bullying. Journal of Adolescent Health, 41 (6): S14-S21

Ybarra, M. L., \& Mitchell, K. J. (2004). Youth engaging in online harassment: Associations with caregiver-child relationships, Internet use, and personal characteristics. Journal of Adolescence, 27, 319-336. 